\title{
Amycolatopsis xylanica sp. nov., isolated from soil
}

\author{
Correspondence \\ Yu-Qin Zhang \\ zhyuqin@126.com \\ Yue-Qin Zhang \\ zyq_0525@yahoo.com
}

\author{
Jie Chen, Jin-Jin Su, Yu-Zhen Wei, Qiu-Ping Li, Li-Yan Yu, Hong-Yu Liu, \\ Yu-Qin Zhang and Yue-Qin Zhang
}

Institute of Medicinal Biotechnology, Chinese Academy of Medical Sciences \& Peking Union Medical College, Beijing 100050, PR China

\begin{abstract}
An actinomycete, designated CPCC $202699^{\top}$, was isolated from soil in Qinghai province, China, and its taxonomic status was established. Strain CPCC $202699^{\top}$ contained meso-diaminopimelic acid in its peptidoglycan, arabinose and galactose as the diagnostic sugars in whole-cell hydrolysates, a phospholipid pattern consisting mainly of phosphatidylethanolamine, phosphatidylmethylethanolamine and phosphatidylcholine, $\mathrm{MK}-9\left(\mathrm{H}_{4}\right)$ as the predominant menaquinone and iso- $\mathrm{C}_{16: 0}(18.8 \%)$, iso- $\mathrm{C}_{15: 0}(18.1 \%)$, iso- $\mathrm{C}_{14: 0}(14.2 \%), \mathrm{C}_{16: 1}$ cis9 $(10.9 \%)$ and $\mathrm{C}_{17: 1}$ cis $9(10.3 \%)$ as the major fatty acids. In the phylogenetic tree based on $16 \mathrm{~S}$ rRNA gene sequences, strain CPCC $202699^{\top}$ formed a separate branch within the genus Amycolatopsis. However, strain CPCC $202699^{\top}$ showed low $16 \mathrm{~S}$ rRNA gene sequence similarities $(<97.0 \%)$ with type strains of species with validly published names in the genus Amycolatopsis. On the basis of genotypic and phenotypic differences from the closest phylogenetic neighbours of strain CPCC $202699^{\top}$, a novel species, Amycolatopsis xylanica sp. nov., is proposed. The type strain is CPCC $202699^{\top}\left(=\mathrm{DSM} 45285^{\top}=\mathrm{KCTC} 19581^{\top}=\mathrm{CCM}\right.$ $\left.7627^{\top}\right)$.
\end{abstract}

The genus Amycolatopsis was proposed by Lechevalier et al. (1986) to accommodate a number of nocardioform actinomycetes. It was later assigned to the family Pseudonocardiaceae on the basis of 16S rRNA gene sequence analysis (Embley et al., 1988; Warwick et al., 1994). Members of the genus Amycolatopsis form branching vegetative hyphae that undergo fragmentation into squarish subunits. Aerial mycelium, if present, may be sterile or may break down into chains of squarish oval fragments or spore-like structures (Lechevalier et al., 1986). Species with validly published names in this genus share the chemotaxonomic characteristics of a type-IV cell wall, arabinose and galactose as the cell-wall sugars, MK$9\left(\mathrm{H}_{4}\right)$ as the major menaquinone, complex mixtures of saturated and branched-chain fatty acids, a type-II or type-III phospholipid pattern and the absence of mycolic acids (Lechevalier et al., 1986). At the time of writing, the genus Amycolatopsis comprised 39 recognized species; Amycolatopsis fastidiosa has since been reclassified as Actinokineospora fastidiosa (Tan et al., 2006; Labeda et al., 2010).

Strain CPCC $202699^{\mathrm{T}}$ was isolated from a soil sample collected in Qinghai province, China, by selective isolation on medium MY10S, which contained xylan as the only

The GenBank/EMBL/DDBJ accession number for the 16S rRNA gene sequence of strain CPCC $202699^{\top}$ is FJ529702.

A thin-layer chromatogram of the phosphate-containing lipids of strain CPCC $202699^{\top}$ and cellular fatty acid profiles of strain CPCC $202699^{\top}$ and related type strains are available as supplementary material with the online version of this paper. carbon and energy source, after incubation at $28{ }^{\circ} \mathrm{C}$ for 2 weeks. Strain CPCC $202699^{\mathrm{T}}$ was maintained on International Streptomyces Project (ISP) yeast extract-malt extract agar slants (ISP 2; Shirling \& Gottlieb, 1966) at $4{ }^{\circ} \mathrm{C}$ and as $20 \%$ (v/v) glycerol suspensions at $-80{ }^{\circ} \mathrm{C}$. Biomass for molecular systematic and chemotaxonomic studies was obtained by cultivation in shake flasks (about 150 r.p.m.) of tryptic soy broth (Difco) at $28{ }^{\circ} \mathrm{C}$ for $5-7$ days.

Colours of substrate and aerial mycelia and soluble pigments were assessed using ISCC-NBS Color Charts (standard sample no. 2106; Kelly, 1964). Spore chains were observed using the coverslip technique (Zhou et al., 1998). Morphological characteristics of spores and mycelia were recorded by examining dehydrated and gold-coated specimens of 1- to 4-week-old cultures grown on ISP 2 and ISP 4 agar by scanning electron microscopy (Quanta; FEI). Conditions for growth were tested on ISP 2 agar at 4, 10, 20, 28, 30, 32, 37, 40 and $45{ }^{\circ} \mathrm{C}$ and with $1,3,5$ and $7-10 \%(w / v) ~ \mathrm{NaCl}$ (at intervals of $0.5 \% \mathrm{NaCl}$ ) and in agar-free ISP 2 medium at $\mathrm{pH} 4.0-11.0$ (at intervals of $0.5 \mathrm{pH}$ units). Freeze-dried cells were used for chemotaxonomic analysis. Utilization of sugars and other compounds listed for the API 50CH and API 20E systems (bioMérieux) and acid production from these sugars were reassessed in basal medium (Shirling \& Gottlieb, 1966) supplemented with $1 \%(\mathrm{w} / \mathrm{v})$ test substrate, with the basal medium as a control. Growth was monitored by measuring the $\mathrm{OD}_{600}$ with an Ultrospec 2000 photometer (Pharmacia Biotech). A fingerprint of enzyme activities was obtained using the API ZYM system (bioMérieux), according to the 
manufacturer's instructions. Sole nitrogen sources were determined in a basal liquid medium containing $\left(1^{-1}\right) 1 \mathrm{~g}$ D-glucose, $0.05 \mathrm{~g} \quad \mathrm{MgSO}_{4} .7 \mathrm{H}_{2} \mathrm{O}, 0.05 \mathrm{~g} \mathrm{NaCl}, 0.001 \mathrm{~g}$
$\mathrm{FeSO}_{4} \cdot 7 \mathrm{H}_{2} \mathrm{O}$ and $0.01 \mathrm{~g} \mathrm{~K}_{2} \mathrm{HPO}_{4}$. Other physiological and biochemical tests were performed according to the established methods of Williams et al. (1983) and Yuan et al. (2008).

Table 1. Phenotypic characteristics that differentiate strain CPCC $202699^{\top}$ from related type strains of the genus Amycolatopsis

Strains: 1, A. xylanica sp. nov. CPCC $202699^{\mathrm{T}}$; 2, A. alba DSM $44262^{\mathrm{T}} ; 3$, A. azurea DSM $43854^{\mathrm{T}} ; 4$, A. coloradensis DSM $44225^{\mathrm{T}}$; 5 , A. decaplanina DSM $44594^{\mathrm{T}}$; 6, A. keratiniphila subsp. keratiniphila DSM $44409^{\mathrm{T}} ; 7$, A. nigrescens DSM $44992^{\mathrm{T}} ; 8$, A. saalfeldensis DSM $44993^{\mathrm{T}}$. All data were obtained in this study. + , Positive; $\mathrm{W}$, weakly positive; - , negative/none.

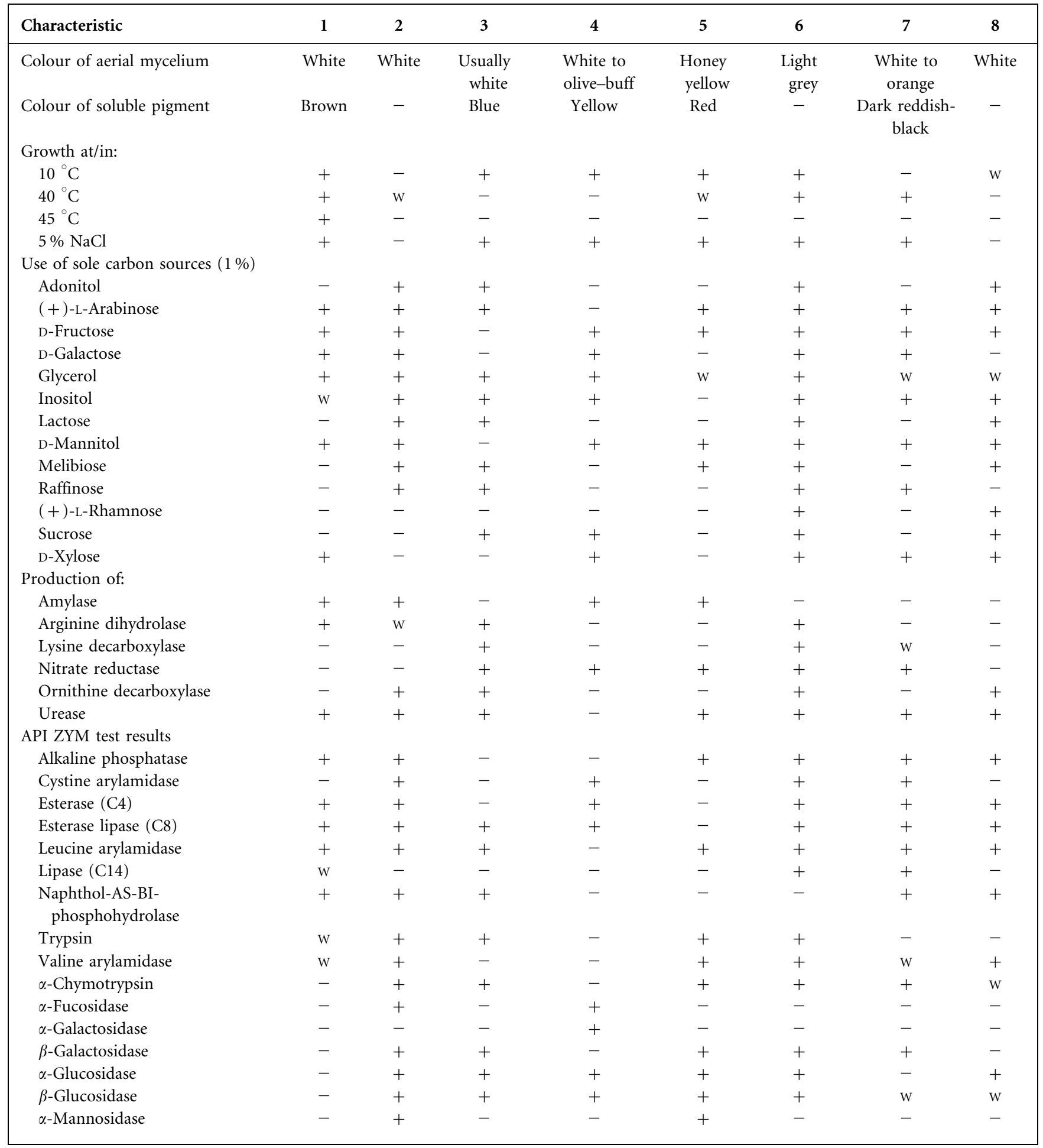


Strain CPCC $202699^{\mathrm{T}}$ displayed the typical morphological properties of the genus Amycolatopsis. The aerial mycelium was white and the substrate mycelium was white-brown to brown on most media tested. Spore surfaces were smooth. Growth was observed at $10-45^{\circ} \mathrm{C}$, at $\mathrm{pH}$ 6.0-9.5 and with $0-5 \%(\mathrm{w} / \mathrm{v}) \mathrm{NaCl}$. Strain CPCC $202699^{\mathrm{T}}$ was catalasepositive and oxidase-negative. Urea, starch and aesculin were hydrolysed, but gelatin was not. Nitrate was reduced. $\mathrm{H}_{2} \mathrm{~S}$ was not produced. Milk was coagulated and peptonized. The detailed physiological and biochemical characteristics of strain CPCC $202699^{\mathrm{T}}$ are given in the species description and Table 1.

The isomer of diaminopimelic acid and the whole-cell sugars were determined following the procedures developed by Hasegawa et al. (1983) and Lechevalier \& Lechevalier (1980). Polar lipids were extracted and identified according to the method of Minnikin et al. (1984). Menaquinones were isolated using the method of Collins et al. (1977) and were analysed by HPLC (Groth et al., 1997). The acid methanolysis procedure was used for the extraction and analysis of mycolic acids (Minnikin et al., 1975). Fatty acids were extracted, methylated and estimated by GC using the standard Sherlock Microbial Identification system (MIDI; Sasser, 1990; Kämpfer \& Kroppenstedt, 1996).

Genomic DNA preparation and PCR amplification of the $16 \mathrm{~S}$ rRNA gene were performed according to Chun \& Goodfellow (1995) and sequencing was performed using an automatic sequencer (ABI PRISM 3730XL; Applied Biosystems). The $\mathrm{G}+\mathrm{C}$ content of the genomic DNA was determined with the thermal denaturation method (Marmur \& Doty, 1962) and Escherichia coli K-12 as a control. Multiple alignments of sequences of members of the genus Amycolatopsis and calculation of sequence similarities were carried out using the EzTaxon server (Chun et al., 2007). A distance matrix and phylogenetic tree were constructed from $K_{\text {nuc }}$ values (Kimura, 1980, 1983) with the neighbour-joining method of Saitou \& Nei (1987) using MEGA version 4.0 (Tamura et al., 2007). The topology of the phylogenetic tree was evaluated by the bootstrap resampling method of Felsenstein (1981) with 1000 resamplings.

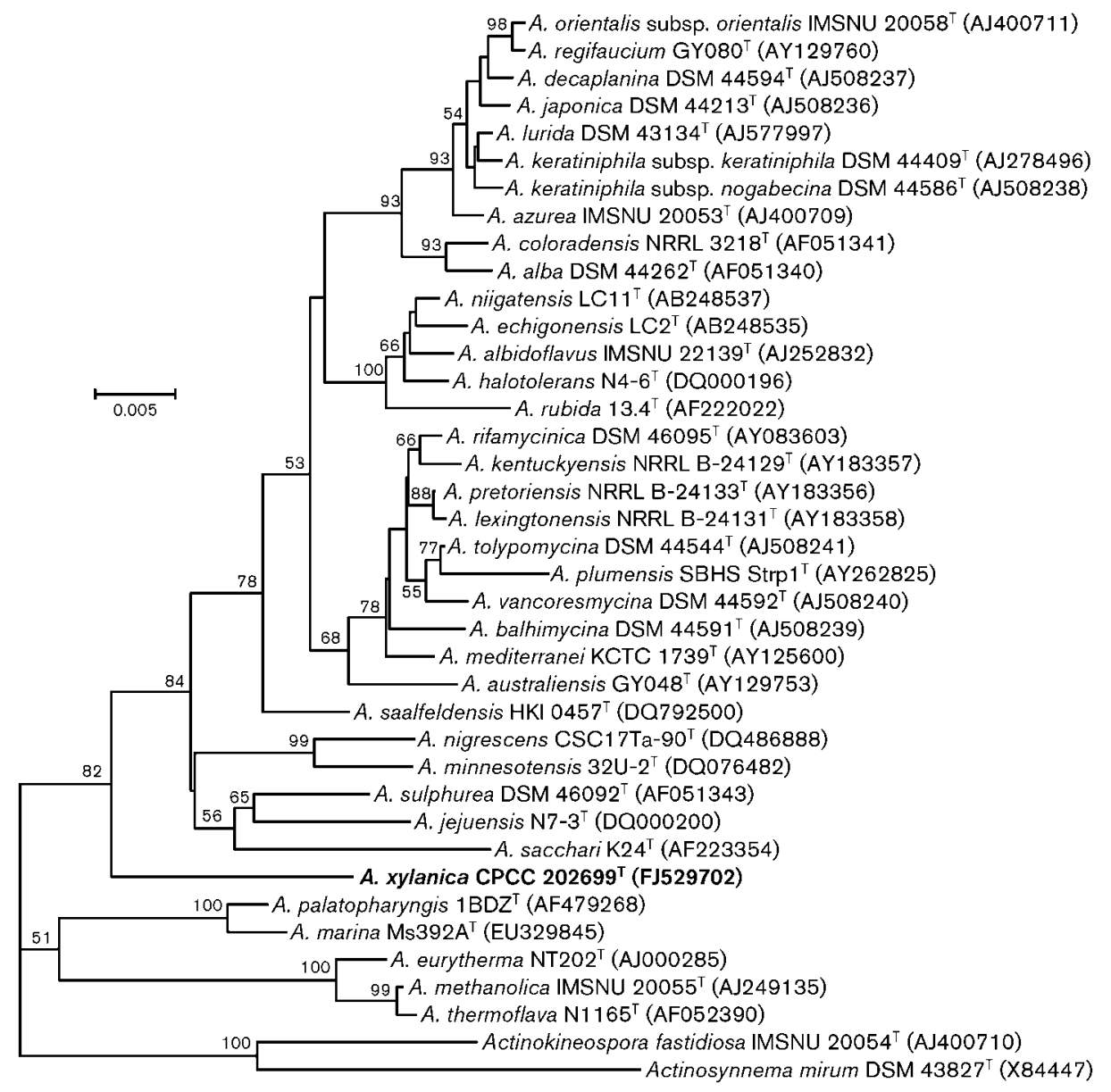

Fig. 1. Neighbour-joining tree, based on almost-complete $16 \mathrm{~S}$ rRNA gene sequences, showing the relationships between strain CPCC $202699^{\top}$ and type strains of the genus Amycolatopsis. Bootstrap values ( $>50 \%$ ) based on 1000 resamplings are shown at branch nodes. Bar, 0.005 substitutions per nucleotide position. 
The cell-wall diamino acid in the peptidoglycan layer of strain CPCC $202699^{\mathrm{T}}$ was meso-diaminopimelic acid and the major sugars in whole-cell hydrolysates were arabinose and galactose (cell-wall chemotype IV according to Lechevalier \& Lechevalier, 1980). The predominant menaquinone was MK$9\left(\mathrm{H}_{4}\right)(83.9 \%)$, with small amounts of MK- $9\left(\mathrm{H}_{6}\right)(11.3 \%)$ and MK- $8\left(\mathrm{H}_{4}\right)(4.7 \%)$. Phosphatidylethanolamine, phosphatidylmethylethanolamine and phosphatidylcholine were predominant in the phospholipid profile (Supplementary Fig. S1, available in IJSEM Online). The major cellular fatty acids were iso- $\mathrm{C}_{16: 0}(18.8 \%)$, iso- $\mathrm{C}_{15: 0}(18.1 \%)$, iso- $\mathrm{C}_{14: 0}$ (14.2\%), $\mathrm{C}_{16: 1}$ cis $9(10.9 \%)$ and $\mathrm{C}_{17: 1}$ cis 9 (10.3\%). The detailed cellular fatty acid profiles of strain CPCC $202699^{\mathrm{T}}$ and related type strains of the genus Amycolatopsis are given in Supplementary Table S1. No mycolates were detected. The genomic DNA G $+\mathrm{C}$ content was $65.9 \mathrm{~mol} \%$.

An almost-complete (1451 nt) 16S rRNA gene sequence of strain CPCC $202699^{\mathrm{T}}$ was determined. Comparison of the sequence with those of representatives of the family Pseudonocardiaceae and other related taxa showed clearly that strain CPCC $202699^{\mathrm{T}}$ was most closely related to members of the genus Amycolatopsis (16S rRNA gene sequence similarities 95.0-96.9\%). In the phylogenetic tree (Fig. 1), strain CPCC $202699^{\mathrm{T}}$ formed a separate branch within the Amycolatopsis clade, which permitted classification of this strain within a novel species of the genus Amycolatopsis (Stackebrandt \& Goebel, 1994; Rosselló-Mora \& Amann, 2001).

Based on the phenotypic differentiation and genotypic data presented above, we propose strain CPCC $202699^{\mathrm{T}}$ to be a representative of a novel species of the genus Amycolatopsis, with the name Amycolatopsis xylanica sp. nov.

\section{Description of Amycolatopsis xylanica sp. nov.}

Amycolatopsis xylanica (xy.la.ni'ca. N.L. n. xylanum xylan; L. fem. suff. -ica suffix used with the sense of pertaining to; N.L. fem. adj. xylanica pertaining to xylan, referring to the energy source used for the isolation of the type strain).

Cells are Gram-stain-positive, aerobic and non-motile and form well-developed aerial and vegetative mycelium. Catalase-positive and oxidase-negative. Colony colour is dependent on the test medium. Aerial mycelium is white on ISP 2, 4 and 5 and Bennett agar. Vegetative mycelium is brown on ISP 2 and Bennett agar, white-brown on ISP 4 and white on ISP 5. Diffusible pigments are light brown on ISP 2, yellow-brown on ISP 4 and ISP 5 and brown on Bennett agar; no discernible diffusible pigments on ISP 6 . The temperature range for growth is $10-45{ }^{\circ} \mathrm{C}$ and good growth is observed at $28{ }^{\circ} \mathrm{C}$. Cells can grow with $0-5 \% \mathrm{NaCl}$, but not with more than $7 \% \mathrm{NaCl}$. Growth occurs at $\mathrm{pH}$ 6.0-9.5 (optimum $\mathrm{pH}$ 7.0-8.0). Utilizes L-alanine, L-arginine, Laspartic acid, L-cystine, L-glycine, L-histidine, hydroxy-Lproline, L-isoleucine, L-leucine, L-phenylalanine, L-proline, Lserine, L-threonine, L-tyrosine, L-tryptophan, L-valine and potassium nitrate as sole nitrogen sources. Utilizes Larabinose, D-fructose, D-galactose, D-glucose, D-lyxose, Dmannitol, D-mannose, trehalose, D-xylose, aesculin ferric citrate, $\mathrm{N}$-acetylglucosamine and glycerol as sole carbon sources for energy and growth, but not D-arabinose, cellobiose, D-fucose, lactose (bovine origin), melezitose, melibiose, raffinose, L-rhamnose, D-ribose, D-sorbose, sucrose, D-tagatose, L-xylose, arbutin, amygdalin, D-adonitol, Dor L-arabitol, dulcitol, erythritol, D-sorbitol, xylitol, methyl $\alpha$-D-glucopyranoside, methyl $\alpha$-D-mannopyranoside, methyl $\beta$-D-xylopyranoside, potassium 2-ketogluconate, potassium 5-ketogluconate, potassium gluconate, D-glycogen, D-inulin or salicin. With API ZYM, positive for alkaline phosphatase, esterase (C4), esterase lipase (C8), leucine arylamidase, acid phosphatase, naphthol-AS-BI-phosphohydrolase and $\mathrm{N}$-acetyl- $\beta$-glucosaminidase, weakly positive for lipase (C14), valine arylamidase and trypsin, but negative for cystine arylamidase, $\alpha$-chymotrypsin, $\alpha$-fucosidase, $\alpha$-galactosidase, $\beta$-galactosidase, $\beta$-glucuronidase, $\alpha$-glucosidase, $\beta$-glucosidase and $\alpha$-mannosidase. Whole-cell hydrolysates contain meso-diaminopimelic acid, arabinose and galactose. The predominant menaquinone is MK-9 $\left(\mathrm{H}_{4}\right)$; small amounts of MK-9 $\left(\mathrm{H}_{6}\right)$ and MK-8 $\left(\mathrm{H}_{4}\right)$ are detected. In the phospholipid profile, phosphatidylethanolamine, phosphatidylmethylethanolamine and phosphatidylcholine are predominant and glucosamine-containing phospholipids, phosphatidylinositol mannosides and phosphatidylinositol dimannosides can also be detected. The major cellular fatty acids $(>10 \%)$ are iso$\mathrm{C}_{16: 0}$, iso- $\mathrm{C}_{15: 0}$, iso- $\mathrm{C}_{14: 0}, \mathrm{C}_{16: 1}$ cis 9 and $\mathrm{C}_{17: 1}$ cis 9 . The genomic DNA G $+\mathrm{C}$ content of the type strain is $65.9 \mathrm{~mol} \%$.

The type strain is CPCC $202699^{\mathrm{T}}\left(=\mathrm{DSM} 45285^{\mathrm{T}}=\right.$ KCTC $\left.19581^{\mathrm{T}}=\mathrm{CCM} 7627^{\mathrm{T}}\right)$, isolated from soil in Qinghai, China.

\section{Acknowledgements}

This work was supported by the National Facilities and Information Infrastructure for Science and Technology (grant no. 2005DKA21203), National S\&T Major Special Project on Major New Drug Innovation (nos 2009ZX09301-003 and 2009ZX09302-004), State-level public welfare scientific research institutes for basic R\&D special fund (no. IMBF200915) and the National Natural Science Foundation of China (NSFC) (grant nos 30970008 and 30570040).

\section{References}

Chun, J. \& Goodfellow, M. (1995). A phylogenetic analysis of the genus Nocardia with $16 \mathrm{~S}$ rRNA gene sequences. Int J Syst Bacteriol 45, 240-245.

Chun, J., Lee, J. H., Jung, Y., Kim, M., Kim, S., Kim, B. K. \& Lim, Y. W. (2007). EzTaxon: a web-based tool for the identification of prokaryotes based on $16 \mathrm{~S}$ ribosomal RNA gene sequences. Int J Syst Evol Microbiol 57, 2259-2261.

Collins, M. D., Pirouz, T., Goodfellow, M. \& Minnikin, D. E. (1977). Distribution of menaquinones in actinomycetes and corynebacteria. J Gen Microbiol 100, 221-230.

Embley, T. M., Smida, J. \& Stackebrandt, E. (1988). The phylogeny of mycolate-less wall chemotype IV actinomycetes and description of Pseudonocardiaceae fam. nov. Syst Appl Microbiol 11, 44-52.

Felsenstein, J. (1981). Evolutionary trees from DNA sequences: a maximum likelihood approach. J Mol Evol 17, 368-376.

Groth, I., Schumann, P., Rainey, F. A., Martin, K., Schuetze, B. \& Augsten, K. (1997). Demetria terragena gen. nov., sp. nov., a new 
genus of actinomycetes isolated from compost soil. Int J Syst Bacteriol 47, 1129-1133.

Hasegawa, T., Takizawa, M. \& Tanida, S. (1983). A rapid analysis for chemical grouping of aerobic actinomycetes. J Gen Appl Microbiol 29, 319-322.

Kämpfer, P. \& Kroppenstedt, R. M. (1996). Numerical analysis of fatty acid patterns of coryneform bacteria and related taxa. Can $J$ Microbiol 42, 989-1005.

Kelly, K. L. (1964). Inter-Society Color Council - National Bureau of Standards Color-Name Charts Illustrated with Centroid Colors. Washington, DC: US Government Printing Office.

Kimura, M. (1980). A simple method for estimating evolutionary rates of base substitutions through comparative studies of nucleotide sequences. J Mol Evol 16, 111-120.

Kimura, M. (1983). The Neutral Theory of Molecular Evolution. Cambridge: Cambridge University Press.

Labeda, D. P., Price, N. P., Tan, G. Y. A., Goodfellow, M. \& Klenk, H.-P. (2010). Emended description of the genus Actinokineospora Hasegawa 1988 and transfer of Amycolatopsis fastidiosa Henssen et al. 1987 as Actinokineospora fastidiosa comb. nov. Int J Syst Evol Microbiol 60, 1444-1449.

Lechevalier, M. P. \& Lechevalier, H. A. (1980). The chemotaxonomy of actinomycetes. In Actinomycete Taxonomy (SIM Special Publication no. 6), pp. 227-291. Edited by A. Dietz \& D. W. Thayer. Fairfax, VA: Society for Industrial Microbiology.

Lechevalier, M. P., Prauser, H., Labeda, D. P. \& Ruan, J.-S. (1986). Two new genera of nocardioform actinomycetes: Amycolata gen. nov. and Amycolatopsis gen. nov. Int J Syst Bacteriol 36, 29-37.

Marmur, J. \& Doty, P. (1962). Determination of the base composition of deoxyribonucleic acid from its thermal denaturation temperature. J Mol Biol 5, 109-118.

Minnikin, D. E., Alshamaony, L. \& Goodfellow, M. (1975). Differentiation of Mycobacterium, Nocardia, and related taxa by thin-layer chromatographic analysis of whole-organism methanolysates. J Gen Microbiol 88, 200-204.
Minnikin, D. E., O’Donnell, A. G., Goodfellow, M., Alderson, G., Athalye, M., Schaal, A. \& Parlett, J. H. (1984). An integrated procedure for the extraction of bacterial isoprenoid quinones and polar lipids. J Microbiol Methods 2, 233-241.

Rosselló-Mora, R. \& Amann, R. (2001). The species concept for prokaryotes. FEMS Microbiol Rev 25, 39-67.

Saitou, N. \& Nei, M. (1987). The neighbor-joining method: a new method for reconstructing phylogenetic trees. Mol Biol Evol 4, 406-425.

Sasser, M. (1990). Identification of bacteria by gas chromatography of cellular fatty acids. USFCC Newsl 20, 16.

Shirling, E. B. \& Gottlieb, D. (1966). Methods for characterization of Streptomyces species. Int J Syst Bacteriol 16, 313-340.

Stackebrandt, E. \& Goebel, B. M. (1994). Taxonomic note: a place for DNA-DNA reassociation and $16 \mathrm{~S}$ rRNA sequence analysis in the present species definition in bacteriology. Int J Syst Bacteriol 44, 846-849.

Tamura, K., Dudley, J., Nei, M. \& Kumar, S. (2007). MEGA4: molecular evolutionary genetics analysis (MEGA) software version 4.0. Mol Biol Evol 24, 1596-1599.

Tan, G. Y., Ward, A. C. \& Goodfellow, M. (2006). Exploration of Amycolatopsis diversity in soil using genus-specific primers and novel selective media. Syst Appl Microbiol 29, 557-569.

Warwick, S., Bowen, T., McVeigh, H. \& Embley, T. M. (1994). A phylogenetic analysis of the family Pseudonocardiaceae and the genera Actinokineospora and Saccharothrix with 16S rRNA sequences and a proposal to combine the genera Amycolata and Pseudoamycolata in an emended genus Pseudonocardia. Int J Syst Bacteriol 44, 293-299.

Williams, S. T., Goodfellow, M., Alderson, G., Wellington, E. M. H., Sneath, P. H. A. \& Sackin, M. J. (1983). Numerical classification of Streptomyces and related genera. J Gen Microbiol 129, 1743-1813.

Yuan, L. J., Zhang, Y. Q., Guan, Y., Wei, Y. Z., Li, Q. P., Yu, L. Y., Li, W. J. \& Zhang, Y. Q. (2008). Saccharopolyspora antimicrobica sp. nov., an actinomycete from soil. Int J Syst Evol Microbiol 58, 1180-1185.

Zhou, Z. H., Liu, Z. H., Qian, Y. D., Kim, S. B. \& Goodfellow, M. (1998). Saccharopolyspora spinosporotrichia sp. nov., a novel actinomycete from soil. Int J Syst Bacteriol 48, 53-58. 